\title{
Pituitary volume and the effects of phototherapy in patients with seasonal winter depression: \\ a controlled study
}

\author{
Volume da pituitáría e os efeitos da fototerapia em \\ pacientes com depressão sazonal de inverno: um \\ estudo controlado
}

\section{Ângela Marisa de Aquino Miranda-Scippa, ${ }^{1}$ Maria Laura Nogueira Pires, ${ }^{2}$ Benjamim Wolf Handfas, ${ }^{3}$ Sueli Kazue Nagahashi Marie, ${ }^{4}$ Helena Maria Calil ${ }^{2}$}

\begin{abstract}
Objectives: Our aims were to investigate the pituitary volume in patients with seasonal winter depression and healthy volunteers in winter and summer, and to assess the effects of phototherapy in these patients. Method: The pituitary volume of 12 patients with winter depression and 12 healthy controls, paired according gender, age and menstrual cycle, were obtained from magnetic resonance imaging in winter and summer. Eight patients were submitted to phototherapy (10000 vs. 2500 lux) in a double-blind crossover fashion during the winter, and reassessed (symptoms and magnetic resonance imaging) after treatment. Results: There were no significant differences in pituitary volume between controls and patients in winter or summer. Exposure to phototherapy (10000 lux) decreased the depressive symptoms ( $p=0.004)$ but the glandular volume did not change $(p=0.5)$. However, the pituitary volume in winter showed a positive correlation with the severity of depression in these patients $(r=0.69, p=0.04)$. Conclusions: The results suggest that neither winter depression nor the change of seasons is associated with significant change in the pituitary volume. Despite the fact that this study was performed in a tropical area, phototherapy with 10000 Iux showed to be an efficient treatment in this SAD patients sample.
\end{abstract}

Descriptors: Pituitary gland; Seasonal variations; Magnetic resonance imaging; Seasonal depressive disorder; Phototherapy

\begin{abstract}
Resumo
Objetivos: Nossos objetivos foram investigar o volume da pituitária em pacientes com depressão sazonal de inverno e controles sadios, no inverno e verão, e avaliar os efeitos da fototerapia nesses pacientes. Método: O volume da pituitária de 12 pacientes com depressão de inverno e 12 controles sadios, pareados quanto ao gênero, idade e fase do ciclo menstrual, foi examinado por meio de imagem por ressonância magnética no inverno e verão. Oito pacientes foram submetidos à fototerapia (10.000 vs 2.500 lux) de forma duplo-cega e cruzada durante o inverno e reavaliados (sintomas e imagem por ressonância magnética) após o tratamento. Resultados: Não houve diferença significativa no volume da pituitária entre controles e pacientes, no inverno e verão. A fototerapia (10.000 lux) reduziu os sintomas depressivos ( $p=0,004)$, mas não alterou o volume glandular $(p=0,5)$. Contudo, o volume da pituitária, no inverno, mostrou uma correlação positiva com a gravidade da depressão nesses pacientes ( $r=0,69, p=0,04)$. Conclusões: Os resultados sugerem que nem a depressão de inverno, nem a mudança das estações estão associadas com a mudança significativa do volume da pituitária. Apesar do fato deste estudo ter sido realizado em uma região tropical, a fototerapia com 10.000 lux mostrou-se um tratamento eficaz nesta amostra.
\end{abstract}

Descritores: Hipófise; Variações sazonais; Imagem por ressonância magnética; Transtorno depressivo sazonal; Fototerapia

\footnotetext{
1 Department of Neuropsychiatry, Universidade Federal da Bahia (UFBA), Salvador (BA), Brazil

2 Department of Psychobiology, Universidade Federal de São Paulo (UNIFESP), São Paulo (SP), Brazil

3 Albert Einstein Hospital, São Paulo (SP), Brazil

4 Department of Neurology, Universidade de São Paulo (USP), São Paulo (SP), Brazil
}

Financing: This study was funded by Conselho Nacional de Desenvolvimento Científico e Tecnológico (CNPq) and Associação Fundo de Incentivo a Psicofarmacologia (AFIP).

Conflict of interests: None

Submitted: April 20, 2007

Accepted: December 5, 2007
Correspondence

Helena Maria Calil

Dept. Psicobiologia - Universidade Federal de São Paulo

Rua Napoleão de Barros, 925 - Vila Clementino

04024-002 São Paulo, SP, Brazil

Phone: (55-11) 2149-0155

E-mail: hmcalil@psicobio.epm.br 


\section{Introduction}

Neuroendocrinological investigations of mental disorders have suggested abnormalities in pituitary function and volume. ${ }^{1,2}$ Imaging studies of major depression have described an increase in the volume of the pituitary in acutely depressed patients. , $^{3,4}$ These results are in agreement with functional studies showing hyperactivity of the hypothalamic-pituitary-adrenal (HPA) axis in this group of patients. ${ }^{5}$ In addition, a reversible enlargement of the adrenal gland, which disappears with remission of symptoms, ${ }^{5-7}$ and an association between a failure to suppress cortisol secretion after dexamethasone administration and pituitary volume have also been reported in patients with major depression. ${ }^{8}$

Seasonal affective disorder (SAD) was first reported in 1984 by a research group at the National Institute of Mental Health (NIMH) and included recurrent episodes of depression, hypomania or mania occuring in specific seasons. Winter seasonal depression occurs in autumn-winter and usually remits spontaneously in spring-summer. ${ }^{9}$ It is a common condition, but its prevalence rates vary among different studies and countries, and it is consistently found to be more common in women. Its clinical picture is characterized by atypical depressive symptoms and response to phototherapy. ${ }^{9,10}$ Like antidepressant drugs, light therapy is an intervention that may act via serotonergic potentiation, although other mechanisms of action - in particular, circadian rhythm phase shifting - are likely to be involved. In contrast to the delayed effect typical of antidepressants, remission of depressive symptoms often occurs within a week of light treatment. ${ }^{10}$ Besides that, light therapy has a low side-effect profile. ${ }^{11,12}$

The pathophysiology of winter seasonal depression is still unknown. ${ }^{10}$ Interestingly, contrary to nonseasonal depression, neuroendocrine studies on SAD patients have shown: 1) normal suppression of cortisol by dexamethasone; ${ }^{13} 2$ ) reduction of adrenocorticotrophic hormone $(\mathrm{ACTH})$ and cortisol response to corticotrophin-releasing hormone $(\mathrm{CRH}) .{ }^{14,15}$ These findings demonstrate hypoactivity of the HPA axis in this group of patients. Indeed, some investigators have suggested that atypical depressions comprise a pathophysiologically separated category of depressions, characterized by hypoactive HPA axis function. ${ }^{5}$

Imaging studies involving patients with $\mathrm{SAD}$ and the effects of seasonality on this gland are scarce, but they suggest that seasonal factors could influence the pituitary size. Moul et al. have demonstrated the decrease in the pituitary volume in healthy volunteers after an experimental exposure to a short photoperiod. ${ }^{16}$ To our knowledge, only one magnetic resonance imaging (MRI) study in patients with winter seasonal depression was performed, and it has not found significant differences in pituitary volumes in comparison to controls. ${ }^{17}$ However, the effects of phototherapy on pituitary size have not been measured before. Therefore, our aims were to investigate the possible variation in the pituitary size between controls and SAD patients during winter and summer, and to assess the effects of phototherapy on these patients.

\section{Method}

Twelve patients who were selected in a previous study at the Clinical Psychobiology Research Center (CPRC) ${ }^{18}$ were interviewed using the Schedule for Affective Disorders and Schizophrenia life time version (SADS-L), and met the diagnostic criteria for depression with a seasonal winter pattern. ${ }^{19}$ An equal number of healthy volunteers paired according to gender, age (range of 2 years) and phase of menstrual cycle at the time of the MRI scans were included. The depressive symptoms were assessed by a psychiatrist (A.M.S.) using the Structured Interview Guide for the Hamilton Depression Rating Scale - Seasonal Affective Disorder Version (SIGH-SAD), ${ }^{20}$ and a minimum total score of 15 was required for inclusion in the study. The patients had been free of psychotropic medication or hormonal treatment for at least three weeks, except for one who had been using clonazepam for a long time. The healthy volunteers were recruited by advertisement placed at the Paulista School of Medicine. They underwent medical history, physical examination, besides the SADS-L interview. None of them used any kind of medication or had mental or physical illnesses. All patients and healthy volunteers were included in the study after signing an informed consent form. The study had previously been approved by the Medical Ethics Committee of Universidade Federal de São Paulo.

\section{Magnetic resonance imaging}

All MRI pituitary scans were run at the Albert Einstein Hospital in São Paulo on a 1.5 Tesla Philips ACS II unit (Philips Medical System Eindhoven, Netherlands) in the winter (July to September) and the following summer (January to March) for both groups. The patients were re-examined in the winter at a mean period of 4 days $(\mathrm{SD} \pm 1.0)$ after finishing the phototherapy with 10000 lux. These exams required no contrast and lasted around 15 minutes each. The subject's head was positioned in a standard quadrature head coil with the canthomeatal line perpendicular to the longitudinal axis of his/her head, and the laser beam centered on the nasion. The MRI protocol consisted of: 1) scout sequences to ensure symmetric positioning of the subject's head; 2) T1 weighed slices in coronal views, graphically determined by the sagittal and axial localizers, and perpendicular to the bicomissural plane, covering the pituitary gland. The scan parameters were three-dimensional fast field echo, $1.5 \mathrm{~mm}$ over contiguous slices with partitions of $0.75 \mathrm{~mm}$ thickness (slice factor 0.5), a 30/9/30/2 (repetition time/echo time/flip angle/ number of excitations) pulse sequence, a matrix size of $256 \times 256$, and a field of view (FOV) of $160 \mathrm{~mm}$; 3) T1 weighed sagittal slices, prescribed from the coronal and axial localizers, centered on the gland. The scan parameters were: two-dimensional spin echo with a 599/20/90/4 pulse sequence; $2.5 \mathrm{~mm}$ noncontiguous slices (slice factor 1.1); matrix size 256 × 256 and a $180 \mathrm{~mm}$ FOV.

The images were transferred to an independent workstation and volumetric measurements were performed with an interactive software (Gyroview HR-software Philips Medical System). Volume was estimated according to Ashtari's proposal: ${ }^{21}$ the regions of interest of each coronal slice were outlined using a manual contouring editing function, and the area was automatically obtained by computer. Thus, the volume was calculated by adding all areas of interest in the coronal views, and by multiplying the total area by the section thickness $(0.75 \mathrm{~mm})$. The volumetric measurements obtained were calculated twice by a neuroradiologist (S.K.N.M.), who was blind to the subject's status with a high reliability $(r=0.95, p<0.05)$.

\section{Phototherapy}

Treatment was morning exposure to bright light (10000 lux) versus lower intensity light (2500 lux) as a control during a 30minute period in a double blind crossover fashion. The light source was a light box (SunRay II, SunBox Company Inc.). The brightness was obtained by varying the distance of the subject to the light box (45 cm = 10000 lux; $95 \mathrm{~cm}=2500$ lux), confirmed with a Gossen photometer (LUNA-PRO) ${ }^{\circ}$. Patients were randomized and rated blindly with the SIGH-SAD before and after each phase of the phototherapy. 
Seven of them underwent treatment at the Clinical Psychobiology Research Center (CPRC) between 6:30 and 8:30 AM during a week in each treatment phase, with an interval of one week between treatments. These patients slept at the CPRC the night before exposure to bright light in order to avoid exposure to sunlight, and control time and duration of treatment. Two patients who were unable to sleep at the CPRC were advised by a team's member (M.L.N.P.) to undergo treatment at home.

\section{Statistical analysis}

Volumetric measures were analyzed with a repeated analysis of variance with diagnosis (patients vs. controls) as group factor and season (winter vs. summer) as the repeated factor. The effect of phototherapy on pituitary volume was analyzed by Student's paired t-test. The SIGH-SAD scores were analyzed using Friedman's analysis of variance by ranks followed by multiple comparison analysis. The correlation between variables was assessed with Pearson product moment coefficient. $P$ value $\leq 0.05$ was considered significant.

\section{Results}

\section{Characteristics of the subjects}

The SAD patients were 7 women (58.3\%) and 5 men (41.6\%), and their mean age was $43.4 \pm 9.6$ years (ranging from 28 to 59 ). This group of patients comprised: 5 patients with major depression ( 2 women, 3 men); 3 subjects with bipolar I disorder (1 woman, 2 men); and 4 women with bipolar II disorder. None of them had received a diagnosis of SAD or had been treated with phototherapy in the past, but half of them had previous pharmacological treatment for depression without therapeutic response. The mean SIGH-SAD total score at the beginning of the study was $25.0 \pm 6.4$, ranging from 17 to 38 (Table 1). The mean age of healthy subjects was $42.9 \pm 9.4$.

\section{Magnetic resonance imaging}

Twelve patients with SAD and 12 paired controls were MRI scanned in winter and none of them had pituitary cyst or adenoma. Three female patients and their matched controls were examined during the follicular phase, another three during their luteal phase, and one in post menopause. One female patient refused to return for her summer scan. Therefore, the MRI data obtained from her and her matched control were excluded from the summer analysis.

The mean \pm SD pituitary volumes for control subjects in winter and summer were $620.3 \pm 130.5 \mathrm{~mm}^{3}$ and $635.2 \pm 146.2 \mathrm{~mm}^{3}$,

Table 1 - Characteristics of SAD patients and their SIGH-SAD scores before phototherapy

\begin{tabular}{|c|c|c|c|c|c|c|}
\hline Patients & $\begin{array}{l}\text { Age } \\
(y)\end{array}$ & Gender & Diagnosis & $\begin{array}{l}\text { Hamilton } \\
21 \text { items }\end{array}$ & $\begin{array}{c}\text { Additional } \\
\text { items }\end{array}$ & $\begin{array}{c}\text { Total } \\
\text { scores }\end{array}$ \\
\hline 1 & 45 & $M$ & MDD & 20 & 11 & 31 \\
\hline 2 & 36 & $\mathrm{~F}$ & BD ॥ & 19 & 19 & 38 \\
\hline 3 & 28 & $\mathrm{~F}$ & BD ॥ & 10 & 11 & 21 \\
\hline 4 & 56 & $M$ & MDD & 11 & 06 & 17 \\
\hline 5 & 59 & $M$ & MDD & 12 & 10 & 22 \\
\hline 6 & 41 & $\mathrm{~F}$ & BD I & 18 & 06 & 24 \\
\hline 7 & 47 & $M$ & BD I & 18 & 04 & 22 \\
\hline 8 & 41 & $M$ & BD I & 11 & 06 & 17 \\
\hline 9 & 40 & $\mathrm{~F}$ & MDD & 18 & 12 & 30 \\
\hline 10 & 56 & $\mathrm{~F}$ & MDD & 20 & 11 & 31 \\
\hline 11 & 33 & $\mathrm{~F}$ & BD II & 14 & 07 & 21 \\
\hline 12 & 39 & $\mathrm{~F}$ & BD II & 15 & 11 & 26 \\
\hline $\begin{array}{l}\text { Mean } \pm S D \\
\text { Median: } \\
\text { MDD: major } \\
B D \text { I: bipola } \\
B D \text { II: bipola }\end{array}$ & \multicolumn{3}{|c|}{$\begin{array}{l}43.4 \pm 9.6 \\
\text { depressive disorder } \\
\text { disorder with mania }\end{array}$} & $\begin{array}{c}15.5 \pm 3.8 \\
16.5\end{array}$ & $\begin{array}{c}9.5 \pm 4.0 \\
10.5\end{array}$ & $\begin{array}{c}25.0 \pm 6.4 \\
23\end{array}$ \\
\hline
\end{tabular}

Table 2 - Pituitary volumes in winter and summer

\begin{tabular}{lccc}
\hline \multicolumn{1}{c}{ Group ( $\mathbf{n})$} & $\begin{array}{c}\text { Age (year) } \\
\text { (Mean } \pm \text { SD) }\end{array}$ & $\begin{array}{c}\text { Winter vol } \mathbf{~ m m}^{\mathbf{3}} \\
\text { (Mean } \pm \text { SD) }\end{array}$ & $\begin{array}{c}\text { Summer vol } \mathbf{~ m m}^{\mathbf{3}} \\
\text { (Mean } \pm \text { SD) }\end{array}$ \\
\hline Patients (12) & $43.4 \pm 9.6$ & $669.2 \pm 125.0$ & $657.5 \pm 96.5$ \\
Healthy subjects (12) & $42.9 \pm 9.4$ & $620.3 \pm 130.5$ & $635.2 \pm 146.2$ \\
\hline
\end{tabular}

ANOVA: factor diagnosis $F\{1.20\}=0.48, p=0.5$; factor season $F\{1.20\}=$ $0.01, p=0.9$; season $x$ diagnosis $F\{1,20\}=0.68, p=0.4$.

respectively. Measures obtained in winter and summer for SAD patients were $669.2 \pm 125.0 \mathrm{~mm}^{3}$ and $657.5 \pm 96.5 \mathrm{~mm}^{3}$, respectively. The ANOVA showed no main diagnosis effect $\left(F_{(1,20)}=0.48, p=0.5\right)$, season $\left(F_{(1,20)}=0.01, p=0.9\right)$ or interaction $\left(F_{(1,20)}=0.68, p=0.4\right)$ as shown in Table 2 .

\section{Phototherapy}

Four patients refused to be treated with phototherapy. Thus, only 8 patients ( 3 women and 5 men) completed both phases of the light treatment protocol. After they were randomized, 6 of them began the treatment with 10000 lux (patients 1, 2, 4, 5, 6 and 7) and 2 (patients 8 and 9) with 2500 lux (Table 3). The Friedman's analysis of variance by ranks revealed a significant difference between the phases of treatment $(p=0.004)$. The multiple comparison analysis reveled that the SIGH-SAD scores before each phase of the treatment did not differ, but exposure to 10000 lux induced a significant reduction in the SIGH-SAD scores ( $22.5 \pm 8.7$ vs. $10.5 \pm 5.1 ; p<0.01)$, whereas lower intensity light (2500 lux) had no significant effect on depressive symptoms ( $17.6 \pm 7.5$ vs. $11.5 \pm 4.0$; NS) - Table 3 .

Data from 8 patients submitted to phototherapy with 10000 lux did not reveal an effect of light exposure on the pituitary volume $\left(668.7 \pm 136 \mathrm{~mm}^{3}\right.$ vs. $\left.688.7 \pm 115 \mathrm{~mm}^{3} ; \mathrm{p}=0.5\right)$. However, the pituitary volumes before phototherapy (10000 lux) were positively correlated with the depression severity $(r=0.69, p=0.04)$. The small sample size did not allow to examine such association following age, gender and menstrual cycle adjustments.

\section{Discussion}

\section{Pituitary measurements}

Due to its excellent anatomical resolution and characterization of tissue, MRI is considered the most adequate neuroimaging technique for assessment of small structures with great variable

Table 3 - SIGH-SAD scores before and after phototherapy

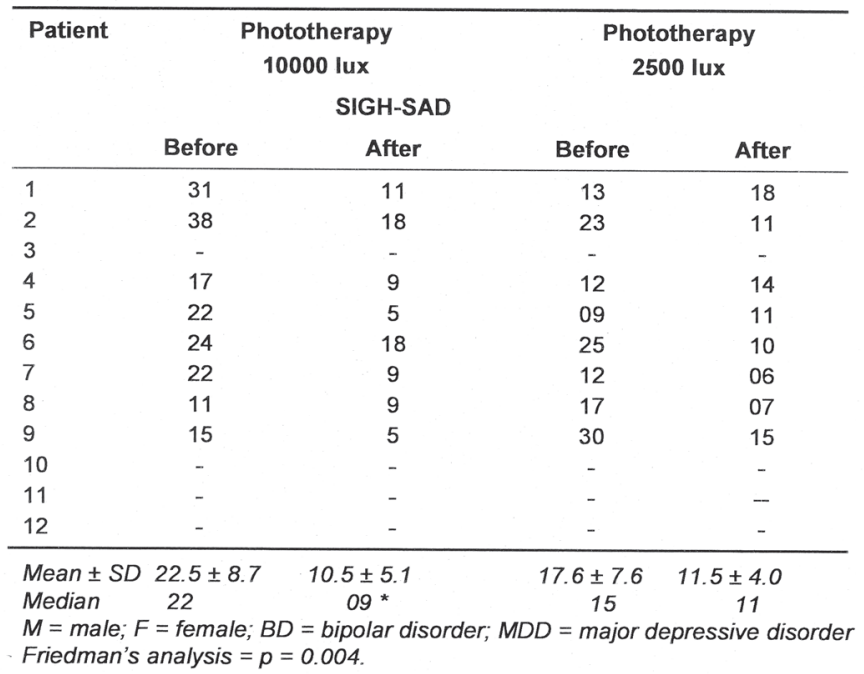


shape, such as the pituitary gland.22 The volume of the pituitary changes during life, and these anatomic changes are believed to reflect the functional status of the gland. MRI studies of the pituitary gland have demonstrated a sudden growth during puberty ${ }^{23}$ and $a$ gradual decrease with age over adulthood. ${ }^{24,25}$ Women tend to have larger glands than men, with additional transient increases during pregnancy and early postpartum period. ${ }^{26-28}$

The results of the present study show no group mean differences in the pituitary volume between patients with SAD and healthy volunteers in winter or summer. These findings are in agreement with those reported by Schwartz et al., ${ }^{17}$ describing similar results of pituitary size in patients with SAD. Thus, the lack of enlargement of the pituitary volume might distinguish patients with SAD from those with major depression. Besides that, this result also suggests a lack of hyperactivity of the HPA axis as shown before. ${ }^{29}$

A positive correlation between the severity of depressive symptoms and the pituitary volume has been found. Although this finding should be considered as preliminary due the small number of patients studied, it might suggest that most severe depressive symptoms could be associated with increased dysfunction of the HPA axis, thus influencing the structural anatomy of involved organs. Consequently, it might be speculated that a significant difference of the pituitary size in patients with SAD and healthy volunteers would depend on the severity of the depressive symptoms or other characteristics of the disease. To our knowledge, there is only one study on winter depression that evaluated this association, but it has not demonstrated a significant correlation between pituitary volume and severity of depression in those patients. ${ }^{17}$ There are several limitations in interpreting the findings of MRI scans in our study. The intracranial volume has been measured as well as the laterality of the subjects. In addition, similarly to a previous study with SAD patients, ${ }^{17}$ we evaluated a small sample with heterogeneous diagnosis, without separating the subjects with bipolar or unipolar disorders. Regarding this aspect, an MRI study on nonseasonal affective disorders has shown that patients with bipolar disorder had significantly smaller pituitary volume than healthy volunteers and patients with unipolar depression, but no differences were found between patients with unipolar depression and control subjects. However, those with bipolar disorders were using lithium during the MRI scans, a potentially confounding variable. ${ }^{30}$ In our study, the SAD bipolar patients had never used lithium.

\section{Response to treatment and changes in pituitary volume}

Two studies in patients with winter depression assessed the effects of phototherapy on cerebral blood flow. Murphy et al. ${ }^{31}$ submitted 4 patients with winter depression to single-photon emission computerized tomography (SPECT) examination, and showed an increased percentage of blood flow in frontal and parietal cortex after a single exposure to light (1500 lux) during a two-hour period, in comparison with healthy subjects undergoing the same experimental procedure. Later, Vasile et al. ${ }^{32}$ examined the cerebral blood flow of 10 patients with SAD before and after phototherapy, and reported an increase of cerebral blood flow only in those patients having who had responded to the treatment. Although these studies have a small number of patients, their findings suggest that phototherapy could modify the function and/or the anatomy of cerebral or glandular structures as shown to occur with pharmacotherapy of patients with major depressive disorder. ${ }^{33}$ In our study, phototherapy with 10000 lux has not significantly changed volume measures, perhaps because the duration of exposure to bright light was brief and thus insufficient to produce structural changes.

\section{Bright light treatment}

This controlled phototherapy study carried out in a tropical area (latitude $23.39^{\circ} \mathrm{S}$ ), where differences in photoperiod across the seasons are not as pronounced as in temperate zones, was effective. Its significant therapeutic effect was only observed after morning exposure to the more intense light (10000 lux). Interestingly, all patients who were treated with 10000 lux in the first or second phase of the crossover had reduction of their depressive symptoms. However, the treatment with 2500 lux in the same conditions induced an increase of the depressive symptoms in three patients ( 1,4 e 5 ) during the second phase of the treatment. These results corroborate previous reports, showing that intensity and duration of exposure are important factors in the mechanism of action of phototherapy. ${ }^{34-36}$ In addition, the efficacy of phototherapy with a bright light (10000 lux) during a 30-minute period adds the advantage of reducing the time of exposure to light, making it more practical and acceptable to patients. ${ }^{37}$

\section{Conclusions}

Our results suggest that neither winter depression nor the change of seasons is associated with significant change in the pituitary volume. This study also confirms the occurrence of SAD in tropical latitudes and the efficacy of phototherapy as an alternative therapeutic tool for winter depressive disorders even in countries with small seasonal photoperiodic variations and high luminosity like Brazil. Therefore, future studies with larger samples, direct endocrine measures, evaluation of seasonality, homogenous samples of patients according to diagnosis (bipolar or unipolar disorders) and their state at the time of the MRI scan (euthymia or acutely depressed) are needed to clarify the differences between seasonal and major depression. In addition, adopting standard approaches to light therapy's specific issues (e.g., defining parameters of active vs. placebo conditions), and incorporating rigorous designs are necessary to evaluate light therapy for winter depression in the Southern Hemisphere.

\section{References}

1. Doraiswamy PM, Krishnan KR, Boyko OB, Husain MM, Figiel GS, Palese VJ, Escalona PR, Shah SA, McDonald WM, Rockwell WJ. Pituitary abnormalities in eating disorders: further evidence from MRI studies. Prog Neuropsychopharmacol Biological Psychiatry. 1991;15(3):351-6.

2. Soares JC, Mann JJ. The anatomy of mood disorders - review of structural neuroimaging studies. Biol Psychiatry. 1997; 41(1):86-106

3. Krishnan KR, Doraiswamy PM, Lurie SN, Figiel GS, Husain MM, Boyko $\mathrm{OB}$, Ellinwood EH Jr, Nemeroff CB. Pituitary size in depression. J Clin Endocrinol Metab. 1991;72(2):256-9.

4. McMaster FP, Kusumakar V. MRI study of the pituitary gland in adolescent depression. J Psychiatr Res. 2004;38(3):231-6.

5. Juruena MF, Cleare AJ, Pariante CM. The hypothalamic pituitary adrenal axis, glucocorticoid receptor function and relevance to depression. Rev Bras Psiquiatr. 2004;26(3):189-201.

6. Nemeroff CB, Krishnan KR, Reed D, Leder R, Beam C, Dunnick NR. Adrenal gland enlargement in major depression. A computed tomographic study. Arch Gen Psychiatry. 1992;49(5):384-7.

7. Rubin RT, Phillips JJ, McCracken JT, Sadow TF. Adrenal gland volume in major depression: relationship to basal and stimulated pituitaryadrenal cortical axis function. Biol Psychiatry. 1996;40(2):89-97. 
8. Axelson DA, Doraiswamy PM, Boyko OB, Rodrigo Escalona P, McDonald WM, Ritchie JC, Paterson LJ, Ellinwood Ehjr, Nemeroff CB, Krishnan $\mathrm{KR}$. In vivo assessment of pituitary volume with magnetic resonance imaging and systematic stereology: relationship to dexamethasone suppression test results in patients. Psych Res. 1992;44(1):63-70.

9. Rosenthal NE, Sack DA, Gillin JC, Lewy AJ, Goodwin FK, Davenport Y, Mueller PS, Newsome DA, Wehr TA. Seasonal affective disorder. A description of the syndrome and preliminary findings with light therapy. Arch Gen Psychiatry. 1984;41(1):72 80.

10. Magnusson A, Partonen T. The diagnosis, symptomatology, and epidemiology of seasonal affective disorder. CNS Spectr. 2005;10(8):625-34.

11. Terman M, Terman JS. Bright light therapy: side effects and benefits across the symptom spectrum. J Clin Psichiatry. 1999;60(11): 799-808.

12. Terman M, Terman JS. Light therapy for seasonal and nonseasonal depression: Efficacy, protocol, safety, and side effects. CNS Spectr. 2005; 10(8):647-63.

13. James SP, Wehr TA, Sack DA, Parry BL, Rogers S, Rosenthal NE. The dexamethasone suppression test in seasonal affective disorder. Compr Psychiatry. 1986;27(3):224-6.

14. Joseph-Vanderpool JR, Rosenthal NE, Chrousos GP, Wehr TA, Skwerer R, Kasper S, Gold PW. Abnormal pituitary-adrenal responses to corticotropin-releasing hormone in patients with seasonal affective disorder: clinical and pathophysiological implications. J Clin Endocrinol Metab. 1991;72(6):1382-7.

15. Oren DA, Levendosky AA, Kasper S, Duncan CC, Rosenthal NE. Circadian profiles of cortisol, prolactin, and thyrotropin in seasonal affective disorder. Biol Psychiatry. 1996;39(3):157-70.

16. Moul DE, Wehr TA, Frank JA. Possible seasonal changes in pituitary size. AJNR Am J Neuroradiol. 1995;16(1):214-5.

17. Schwartz PJ, Loe JA, Bash CN, Bove K, Turner EH, Frank JA, Wehr TA, Rosenthal NE. Seasonality and pituitary volume. Psychiatry Res. 1997;74(3):151-7.

18. Calil HM, Hachul D, Juruena MF, Crespin J, Pires MI. Evaluacion de alteraciones estacionales en comportamiento en la ciudad de San Pablo. Acta Psiquiatr Psicol Am Lat. 2000;46(2):109-18.

19. Spitzer RL, Endicott J. The Schedule for Affective Disorders and Schizophrenia. Life time version - SADS-L. 3rd ed. New York: Department of Biomedics Research, New York State Psychiatry Institute; 1979.

20. Williams JB, Link MJ, Rosenthal NE, Terman M. Structured Interview Guide for the Hamilton Depression Scale-Seasonal Affective Disorder Version (SIGH-SAD). New York: New York State Psychiatry Institute; 1988.

21. Ashtari M, Zito JL, Gold BI, Lieberman JA, Borenstein MT, Herman PG. Computerized volume measurement of brain structure. Invest Radiol. 1990;25(7):798 805.

22. Abou-Saleh MT. Neuroimaging in psychiatry: an update. J Psychosom Res. 2006;61(3):289-93.

23. Takano $\mathrm{K}$, Utsunomiya $\mathrm{H}$, Ono $\mathrm{H}$, Ohfu M, Okazaki M. Normal development of the pituitary gland: Assessment with three-dimensional MR volumetric. AJNR Am J Neuroradiol. 1999;20(2):312-5.

24. Lurie SN, Doraiswamy PM, Husain MM, Boyko OB, Ellinwood EH Jr, Figiel GS, Krishnan KR. In vivo assessment of pituitary gland volume with magnetic resonance imaging: the effect of age. J Clin Endocrinol Metab. 1990;71(2):505-8.

25. Doraiswamy PM, Potts JM, Axelson DA, Husain MM, Lurie SN, Na C, Rodrigo Escalona P, McDonald WM, Figiel GS, Ellinwood EH Jr. MR assessment of pituitary gland morphology in health volunteers: age and gender-related differences. AJNR Am J Neuroradiol. 1992;13(5):1295-9.

26. Gonzalez JG, Elizondo G, Saldivar D, Nanez H, Todd LE, Villarreal JZ. Pituitary gland growth during normal pregnancy: an in vivo study using magnetic resonance imaging. Am J Med. 1988;85(2): 217-20.

27. Elster AD, Sanders TG, Vines FS, Chen MY. Size and shape of the pituitary gland during pregnancy and post partum: measurement with MR imaging. Radiology. 1991;181(2):531-5.

28. Miki Y, Kataoka ML, Shibata T, Haque TL, Kanagaki M, Shimono T, Okada T, Hiraga A, Nishizawa S, Ueda H, Rahman M, Konish J.
The pituitary gland: changes on MR images during the 1st year after delivery. Radiology. 2006;235:999-1004.

29. Juruena MF, Cleare AJ. Superposição entre depressão atípica, doença afetiva sazonal e síndrome da fadiga crônica. Rev Bras Psiquiatr. 2007;29(Suppl. 1):S1-16.

30. Sassi RB, Nicolletti M, Brambilla P, Harenski, K, Mallinger AG, Frank E, Kupfer DJ, Keshavan MS, Soares CJ. Decreased pituitary volume in patients with bipolar disorder. Biol Psychiatry. 2001;50(4): 271-80.

31. Murphy DG, Murphy DM, Abbas M, Palazidou E, Binnie C, Arendt J, Campos Costa D, Checkley SA. Seasonal affective disorder: response to light as measured by electroencephalogram, melatonin suppression, and cerebral blood flow. Br J Psychiatry. 1993;163: 327-31, 335-7.

32. Vasile RG, Sachs G, Anderson JL, Lafer B, Matthews E, Hill T. Changes in regional cerebral blood flow following light treatment for seasonal affective disorder: responders versus nonresponders. Biol Psychiatry. 1997;42(11):1000-5.

33. Pillay SS, Yurgelun-Todd DA, Bonello CM, Lafer B, Fava M, Renshaw PF. A quantitative magnetic resonance imaging study of cerebral and cerebellar gray matter volume in primary unipolar major depression: relationship to treatment response and clinical severity. Biol Psychiatry. 1997;42(2):79-84.

34. Wirz-Justice A, Schmid AC, Graw P, Krauchi K, Kielholz P, Poldinger W, Fisch HU, Buddeberg C. Dose relationships of morning bright white light in seasonal affective disorders (SAD). Experientia. 1987;43(5):574-6.

35. Avery D, Khan A, Dager S, Cohen S, Cox G, Dunner D. Is morning light exposure superior to evening in treating seasonal affective disorder? Psychopharmacol Bull. 1990;26(4):521-4.

36. Terman JS, Terman M, Schlager D, Rafferty B, Rosofsky M, Link MJ, Gallin PF, Quitkin FM. Efficacy of brief, intense light exposure for treatment of winter depression. Psychopharmacol Bull. 1990;26(1):3-11.

37. Golden RN, Gaynes BN, Ekstrom RD, Hamer RM, Jacobsen FM, Suppes T, Wisner KL, Nemeroff CB. The efficacy of light therapy in the treatment of mood disorders: a review and meta-analysis of the evidence. Am J Psychiatry. 2005;162(4):656-62. 